\title{
Catholic Identity through the Lens of the School's Official Website
}

\section{RANDY A. TUDY}

http://orcid.org/0000-0001-6535-6129

randytudy@cjc.edu.ph

Cor Jesu College

Philippines

\author{
STEPHEN. F. GAMBESCIA \\ http://orcid.org/0000-0003-2180-1678 \\ sfg23@drexel.edu \\ DREXEL University \\ United States of America
}

\begin{abstract}
Catholic identity is a mark that separates Catholic schools from secular ones. One important tool for communicating this marker is through the school's website. The aim of the study was to look into the official websites of Catholic schools in the Philippines and to find out how they explicate their Catholic identity. Using the document Ex Corde Ecclesiae, seven markers were used. It employed descriptive research design replicating the methods used by Gambescia and Paolucci in 2011. The result revealed that the Lead Academic Statement is present in 73 out of 75 schools. This is followed by Affiliation with Sponsoring Catholic Entity, 71; Catholic Heritage, 55; Catholic Service, 45; Catholic Worship, 37; Catholic on Homepage, 16; and Human Resource Page, 0. Overall, 297 markers were counted out of the expected 525. Thus, the schools in the Philippines have explicated Catholic identity especially on the first three markers, but much attention should be focused on the bottom four. The study should
\end{abstract}


also investigate the presence of these markers but should not judge the totality of a particular level of Catholicity. However, the school website should not be underestimated in its role to explicate Catholic identity.

\section{KEYWORDS}

Social Sciences, Religion, Catholic identity, schools' official website, descriptive design, Philippines

\section{INTRODUCTION}

News about Pope Benedict XVI entering the Twitter world was not a surprise. While reputedly conservative, this pope knew the power of social media and its impact on people. During the celebration of the 47th World Communications Day, the pontiff urged the faithful to use social network to spread the faith (Musil, 2013). His predecessor, Pope John Paul II, already recognized the use of mass media. In the apostolic letter "Rapid Development", Pope John Paul II highlighted the vital role of communications media as part of the framework of the Church's evangelization (John Paul II, 2005). Furthermore, the advent of the internet has given the Church potent means to advance her mission. The internet provides a wider reach for the Church to her people.

As a strong educational arm of the Church, Catholic schools are also challenged to use this tool to bring the message of salvation. To have easy access to the life, mission, programs and activities, schools create websites to provide quick and broad means for students and other school stakeholders. Therefore, a school's website serves as a primary means of communication where students can learn about the school (Klein, 2005; Stoner, 2004; Gambescia \& Paolucci, 2011). Initial impressions and messages, regardless of channel is supported by Solan and Gambescia (2010) who considered student recruitment messaging a "first promise" to students for what they will receive from a particular school. For example, students will know that a Catholic school doesn't only educate the mind but also the heart (Petrusch, 2011). Through the website, parents will be made aware if their desire to have a Catholic education is fitted to what they expect. It was reported that they want to send their children to Catholic school because they believe in its effective discipline (Glazer, 2014). Hence, it is very important for parents and students to know first the kind of school they want, and the easiest way to get information is through the school's official website. 
Following this line of thinking, it is assumed that the website can also be a way of identifying the Catholic identity (Catholicity) of each Catholic school. There had been several attempts to explain the Catholic identity of Catholic schools (Congregation for Catholic Education, 1977; Brennan, 2012; O'Connel, 2012; Convey, 2012 \& Krebbs, 2012). Moreover, Pope John Paul II summarized the notion of Catholic identity through Ex Corde Ecclesiae. In this encyclical, he enumerated the marks of being Catholic:

"1) a Christian inspiration not only of individuals but of the university community as such; 2) a continuing reflection in the light of the Catholic faith upon the growing treasury of human knowledge, to which it seeks to contribute by its research; 3) fidelity to the Christian message as it comes to us through the Church; and 4) an institutional commitment to the service of the people of God and of the human family in their pilgrimage to the transcendent goal which gives meaning to life (John Paul, 1990).”

These are the basic components of the identity of Catholic universities that ensure a Christian presence in the school community. Most of the points raised in this encyclical were also mentioned in The Catholic School, a document written in 1977 about the nature and identity of Catholic schools (Congregation for Catholic Congregation, 1977). Moreover, Ex Corde Ecclesaie touches the fundamentals of Catholic identity with its pastoral implication to Catholic schools in the modern world. Further, the nature and identity of Catholic schools are centered on the person of Christ (Brennan 2012; O'Connel, 2012). While centrality to Christ is an obvious reference to Catholic schools' identity, the faith of the school community expressed in tangible terms is considered a true mark of being Catholic (Convey, 2012). Regardless of beautiful buildings, worldclass equipment and high standard programs, Catholic identity is seen in the witnessing of the people involved especially the direct stakeholders of the school community.

To promote school's programs, services, and even identity, most schools use their websites for easy access of their clients or stakeholders. However, there is scarcity of data to prove that a school's website provides adequate information to promote the school's Catholicity. This study proposes a new way of looking at the Catholicity of Catholic schools in the Philippines. Proud of its title as the only Christian Country in Asia where about 81 \% of the population is Catholic (De Guzman, 2011), the Philippines carries the torch of Catholicism especially in this part of the planet. The Church in the Philippines, after 400 years of Catholic education, continues to rely on the influence of Catholic schools to the young people. 
In 2011, Gambescia and Paolucci (2011) studied the extent of Catholicity of Catholic schools in the United States by evaluating the schools' websites. They found out that the official websites communicate some level of their identity as Catholics, but there were surprisingly many gaps in explicating a strong Catholic identity via this ubiquitous medium.

\section{OBJECTIVES OF THE STUDY}

Schools' websites have taken major supporting roles in communicating their mission, purpose, objectives, academic programs, and overall student experience. Schools that are ostensibly Catholic "express" their Catholic identity to all prospective and current students and other constituents unambiguously. This project is a replication of the work of Gambescia and Paolucci (2011). Using the same methodology, this study looked at the official websites of Catholic colleges and universities in the Philippines and how they explicate their Catholic identity.

\section{METHODOLOGY}

The method used for this study very closely replicated the work of Gambescia and Paolucci (2011) who analyzed the websites of 206 Catholic colleges in the United States to assess how the colleges explicate their Catholic identify. The study can be considered a replication of their study in method and protocol but differs in the fact that it examined the Catholic colleges in the Philippines. As they noted, Catholic identity of a college can be exercised in many ways because Catholic teaching and discipline are to influence "all university activities," and "any official action commitment of university is to be in accord with its Catholic identity" (John Paul II, 1990). It is understood that the authenticity of these activities as Catholic cannot all be assessed simply by reviewing the college's official website. For example, the rationale for the core curriculum meeting the Catholic mission may not be evident from material posted in the website. This would take a thorough review of the college's official core curriculum documents.

However, it is fair to expect that enough Catholic "markers" are visible to lead the reader, and most importantly the students and faculty, to believe that the college is true to its Catholic identity. The approach in this study is first to identify basic markers that one would expect a Catholic college would display on its official website for prospective students and the colleges' constituents, thereby providing an aggregate accounting for how the Catholic colleges in the Philippines are doing in explicating their Catholicity. This approach was selected 
because of the growing public nature of college websites in the Philippines versus traditional means of communicating a college's purpose and mission, (e.g., view books, pamphlets, newspaper advertisements). As websites become more popular, they can be considered the first promise (Solan \& Gambescia, 2010) in the college experience.

\section{Markers Examined to Assess Catholic Identity}

For the purpose of this study, several markers were used to assess the nature and extent of how colleges explicate their Catholic identity via their websites. There are several ways that Catholic colleges can communicate their commitment to Catholic identity. The value they put in communicating that via their website may or may not have been well vetted among college leaders and the faculty. The markers below meet the spirit of colleges expressing their publicly professed identity to prospective and current students. Catholic colleges are explicating unambiguously their Catholicity on their website when they include information or makers such as the ones chosen for this study. These seven markers represent the spirit of the four essential characteristics of a Catholic college as expressed in Ex Corde Eccesiae. There are other markers, such as establishing centers and institutes of Catholic teaching and research, but these seven markers meet a high publicly professed Catholic standard.

"Catholic" on home page. The first marker is the statement on the home page that the college is currently "Catholic," not simply historically Catholic. One would assume this to be the most basic marker. A goal of any organization's home page is to give immediate and even lasting identity. Using the term Catholic on the home page is a reasonable expectation.

Affiliation with sponsoring Catholic organization. A second marker for this study is whether the college explains on its webpage or links from the home page (e.g., "History" or "About us") that there is active and significant sponsorship from a recognized Catholic religious order or Catholic diocese. Colleges take pride in their mission; therefore, one would expect that Catholic colleges articulate their mission about some aspects of their Catholic tradition. Sponsorship takes several forms, such as governance, teaching, spiritual, intellectual, and service influences, and significant commitment of resources.

Lead academic statement. The college should clearly state in what can be considered its major statement of academic purpose, goals, or objectives that students receive an education that is influenced by one or more of the flowing Catholic elements: Catholic Intellectual Tradition, Catholic theology, Catholic Church doctrine and teaching, Catholic spirituality, and Catholic social justice. 
This marker borrows directly from the four essential elements identified by Ex Corde Eccelesiae, including a commitment to the Christian message and service.

Human resources page. Another marker identified for this study will be whether the college clearly states in the job section or human resources section that the College is Catholic and expects that current and prospective employees, including faculty, will recognize and respect its mission and purpose. This reflects Ex Corde's call for Christian inspiration of individuals and the university community.

Catholic worship. The college should demonstrate that there are Catholic worship opportunities such as devotions, sacramental opportunities, liturgical offerings, prayer services, Holy Day activities, formal faith exploration activities, and overall active campus ministry activities. The link to evidence should be no more than two clicks from the home page. Such high-level placement shows that the college values these activities in the overall experience for members of this campus community. This reflects the need for Catholicism to be "virtually present and operative" (John Paul II, 1990).

Catholic social service. The college should demonstrate evidence of Catholic service, including opportunities to serve the poor and disadvantaged, service learning opportunities, formal programs to learn about and participate in social justice and support of formal programs of Catholic-based volunteer corps (e.g. Jesuit Volunteer Corps.). John Paul II (1990) said, "Institutional commitment to the service of the people of God and the human family" (n.13) is essential for Catholic colleges. The marker reflects these characteristics.

Catholic heritage. The college should provide evidence of its Catholic heritage on its website by using photographs, images or symbols that are clearly identified as Catholic (e.g. places on worship, crucifix, members of the clergy or religious order, patron saint artwork or statue, highly recognized Catholic symbols). Catholic colleges are to express "institutional commitment" to Catholic identity (John Paul II, 1990, n 14). Symbols are one important form of expressing this commitment.

\section{Website Review Protocol}

Universities and colleges selected for analysis will come from the list of Catholic colleges and universities in the Catholic Educational Association of the Philippines (CEAP). After removing seminaries from the list, a total of 75 colleges and universities were identified for review. Again the protocol used for reviewing these schools' website to identify these seven markers follows the Gambescia and 
Paolucci study (2011).

A random set of 20 colleges from the 75 colleges was reviewed to ensure consistency in the understanding of the categorization and assessment of the seven markers by the authors. After consistency had been established, all 75 school websites were reviewed. In looking for the presence of these markers, the process of reliability ranges from a straightforward step to an iterative process. For example, the marker to see if the word Catholic is used on a college's home page is straightforward and unlikely to be overlooked. However, to search for and identify the college's major statement of academic purpose or objectives required much more review, as colleges placed this statement in various locations on their websites and used various ways to communicate the statement. Some colleges had a brief and formal academic purpose statement. Other colleges used longer narratives and a list of educational objectives, or language that could be considered for marketing or branding purposes. To determine if a college gave evidence of its Catholic heritage on its website by using photographs, images, or symbols that are clearly identified as Catholic was a more subjective judgment, calling for re-review and more discussion.

At some level, these markers had res ipsa loquitar utility. Conducting this review of all seven markers necessitated reading through a minimum of 12 pages on a college's website.

Table 1. A guide on tracking Catholic markers on the schools' official website

\begin{tabular}{llll}
\hline Marker & $\begin{array}{l}\text { Webpage } \\
\text { Exposure }\end{array}$ & Disposition & \\
\hline $\begin{array}{l}\text { "Catholic" on } \\
\text { homepage }\end{array}$ & 1 & Present & Not present \\
$\begin{array}{l}\text { Affiliation with } \\
\text { Catholic sponsoring } \\
\text { entity }\end{array}$ & $2-3$ & Explained & Not explained \\
$\begin{array}{l}\text { Lead Academic } \\
\text { Statement }\end{array}$ & $2-4$ & States Catholic influence & $\begin{array}{l}\text { Does not state Catholic } \\
\text { influence }\end{array}$ \\
$\begin{array}{l}\text { Human Resource Page } \\
\text { Eo statement about employee's } \\
\text { obligation to respect Catholic } \\
\text { mission and identity } \\
\text { Catholic Worship }\end{array}$ & $3-4$ & $\begin{array}{l}\text { Catholic mission and } \\
\text { identity }\end{array}$ & $\begin{array}{l}\text { Two clicks to Campus two clicks to } \\
\text { Campus Ministry }\end{array}$ \\
Catholic Service & $4-6$ & $\begin{array}{l}\text { Evident } \\
\text { Symbolism strong }\end{array}$ & $\begin{array}{l}\text { Not evident } \\
\text { Symbolism not strong }\end{array}$ \\
\hline
\end{tabular}


However, in most cases the reviews were 20 pages and beyond, which gave us good exposure to the website in which to make an assessment on the extent of Catholic identity given to a reader of these websites (see Table 1). We discussed any questionable material to see if it qualified as a clear and unambiguous Catholic identity marker. More details related to the validity and reliability of the method were discussed in the findings and limitations of this study where concrete examples were given for how these colleges explicate their Catholicity. It is important to note that the purpose of the study was not to judge the design of the website or how effective the information is at communicating a college's Catholic identity. Rather, the purpose was to determine the presence of and to some extent the nature of Catholic markers.

\section{RESULTS AND DISCUSSION}

The study looked at how the seven markers were present in the school's website. As mentioned earlier, absence of these markers does not mean less extent of Catholicity. But as schools' websites take on a prominent mode of communicating the purpose and mission, it is reasonable to expect that colleges will make their Catholicity quite visible.

\section{Extent of Seven Catholic Identity Markers Used by Catholic Colleges and Universities}

The first part of the analysis focused on the extent of each of the seven markers as reflected in the website of the schools under study.

Table 2. Extent of Seven Markers present in Schools' Website $(\mathrm{N}=75)$

\begin{tabular}{llll}
\hline \# of markers present & $\mathrm{N}$ & $\%$ & Rank \\
\hline 0 & 0 & 0.00 & 7 \\
1 & 1 & 1.33 & 6 \\
2 & 8 & 10.67 & 4 \\
3 & 14 & 18.67 & 3 \\
4 & 29 & 38.67 & 1 \\
5 & 16 & 21.33 & 2 \\
6 & 7 & 9.33 & 5 \\
7 & 0 & 0.00 & 7 \\
\hline
\end{tabular}


Out of the seven markers, it is worth noting the frequency of attributes present in the schools' websites. As shown in Table 2, none of the schools under study manifested all seven markers of Catholicity. On the other hand, no school manifested no marker at all. The majority of the schools have four markers visible on their website which accounts for $38.67 \%$. This is followed by 16 schools $(21.33 \%)$ which have five markers and 14 schools (18.67\%) with three markers. Eight schools (10.67\%) have two markers and seven schools $(9.33 \%)$ show six Catholic markers. The data revealed that of the expected seven markers, most of the schools in the study reflect only three to five markers on their websites. The result also showed a dispersed distribution when it comes to how many markers are present.

\section{Frequency of Seven Markers Used on school websites}

The second part of the analysis was focused on the Catholic identity markers and the frequency of their presence in the websites of the schools under study.

Table 3. Frequency on the presence of Catholic Markers on school websites $(\mathrm{N}=75)$

\begin{tabular}{llll}
\hline Markers & $\mathrm{N}$ & $\%$ & Rank \\
\hline Catholic on homepage & 16 & 21.33 & 6 \\
Affiliation with sponsoring Catholic entity & 71 & 94.70 & 2 \\
Lead Academic statement & 73 & 97.33 & 1 \\
Human resource page & 0 & 0 & 7 \\
Catholic worship & 37 & 49.33 & 5 \\
Catholic Service & 45 & 60.0 & 4 \\
Catholic heritage & 55 & 73.33 & 3 \\
Total & $297 / 525$ & $56.57 \%$ & \\
\hline
\end{tabular}

In Table 3, findings show that almost all of the schools have clearly reflected their lead academic statement with Catholic identity. Seventy-three schools or $97.33 \%$ have clearly articulated Catholicity in the vision, mission or other academic statements. For example, Miriam College calls itself as a "premier Catholic institution of learning" and St. Scholastica College as a "Catholic Benedictine educational institution". Moreover, there are schools which have made a bolder pronouncement by singling out its religious formation or religion subject as the core curriculum. This is found in the websites of St. Theresa's College, Canossa College, and Colegio de Purisima. St. Paul University Surigao, 
on the other hand, considers Christian formation as the core of Pauline education.

Not to confuse with the use of the terms, some schools would like to relate being Christian to Catholic. This is quite interesting because, in a country such as the Philippines, the term Christian is seemingly acceptable to mean Catholic. This is not the case in other countries. Christian churches, which are not Catholic, call their members Christians. Hence, for San Sebastian College, it clearly distinguishes Catholicity by saying "The cultivation of Christian (Catholic) and Vincentian values among the members of the school family so that they can participate in their growth towards total human development." Take note that this school still uses the term Christian but to make sure it is clear the word Catholic is put in parenthesis for emphasis.

Ranked number 2 as the most used marker is the school's Catholic affiliation or sponsorship. Seventy-one schools or $94.7 \%$ have diligently explained their affiliation with a Catholic religious order or diocese. This marker can be found in the history section which reveals their Catholic affiliation or religious foundation. Naturally, schools, which are run and administered by religious congregations, have usually narrated their affiliations in the historical account. For instance, all Jesuit universities, such as Ateneo de Davao, Ateneo de Manila and Xavier University, would have this pronouncement "A Filipino, Catholic and Jesuit University". The same is true with Colegio San Agustin-Bacolod, which calls itself Catholic, Filipino, Augustinian school. St. Paul University is true to its name and its affiliation. Its vision mission clearly defines itself and the congregation- "St. Paul University is a Marian and Pauline community of disciples deeply rooted in Christ." Diocesan schools also explicated and asserted their Catholicity. For example, Urius University has the following declaration: "Father Saturnino Urios University is a Filipino, Catholic, diocesan, educational institution".

For Catholic schools to be clearly identified on the external manifestations, symbols are one obvious answer. Catholic heritage ranked third with 55 or $73.33 \%$ schools have it in their websites. These manifestations include photographs, images, and symbols found in the website which portray Catholic heritage or identity. Among the common symbols found were crosses, statues, and liturgical symbols.

Ranked number four is Catholic Service. Forty-five schools or $60.0 \%$ have it reflected in their website. This is usually written and explained through the school's community extension or engagement program.

The statement from Columban College states that its students "participate and engage in outreach activities and enhance academics through exposures in 
the adopted communities of the school." The school considers this as its best feature to promote authentic Christian values.

St. Louis University, through its Medical Outreach Missions Foundation, Inc. (MOMFI), promotes health by educating the rural populace on matters pertaining to Primary Health Care, Maternal \& Child Care, Environmental Sanitation, Nutrition, and Personal Hygiene. For Notre Dame of Dadiangas University and through its community extensions, it provides a venue for greater participation of the Administration, Faculty, Support Service Personnel and Students in the community extension programs of the school.

Catholic Worship ranks fifth. This marker refers to worship, liturgical celebrations, and other religious practices found in the websites. The easiest way to find this particular marker is through the Campus Ministry. Only about half or 37 schools show this mark in their websites. Not all schools have the link to their Campus Ministry Office. This marker is expected and is easily recognized by those who visit the website. However, pictures of Prayer and other liturgical celebrations which are evident in the website give the impressions for visitors to think that it is a Catholic school. For Cor Jesu College, its Campus Ministry "contributes to the realization of the school's vision-mission by striving to build a school community of believers that worships serves and witnesses the compassionate love of God."

Ranked sixth is the use of the actual word "Catholic" as a marker on the school's homepage. Only 16 schools or $21.33 \%$ have the word "Catholic" on their homepage. It was assumed in this research that the school's Catholic marker is clearly seen right on its homepage, thus, giving a clear impression to the visitors its Catholic identity. Obviously, schools which have the word Catholic on their name surely get a point for this marker, like Binangonan Catholic College, Cainta Catholic College, and Aklan Catholic College.

For other schools with the word Catholic attached to their name, a careful review and search were done. Among the 25 schools, some notable examples are those schools which have the word Catholic written just below the institution's name. For example, St. Paul University Manila had this line "Social Transformation through Catholic Education." "The Catholic University of the Philippines" is the tagline for University of Santo Tomas. Holy Name University proudly claimed as the "Premier Catholic University in the Province of Bohol." Some of the schools have the word Catholic written somewhere within the homepage. Others have a description of the school written on the right side or at the bottom page or in the moving pictures of the website as in the case of Miriam College. 
Surprisingly, not a single school had a Catholic marker on its human resource page. In fact, majority of the schools did not have a link to this office. Ex corde called on colleges to seek out Catholic leadership and while not saying non-Catholics should not be employed the college should make it clear to all employees, especially the leadership of the Catholic tradition and mission.

Overall, 297 markers or $56.57 \%$ were counted out of the full complement 525 based on 75 schools under study. Clearly the Internet has become a major source of information for consumers, even consumers of products as personal and high investment as picking a college. A college's homepage has become a valuable tool in which to present the college's mission and purpose and its strategic difference. College home pages are fast replacing the ubiquitous view books and other collateral recruitment material. A college's homepage will grow in its importance as colleges become more sophisticated in their use. One would hope that what is communicated via a college's website is authentically what students can expect of the college experience or its initial promise (Solan \& Gambescia, 2010).

The primary mission of a college is the academic formation of a student. If a college presents itself as Catholic, one would expect that the academic formation in some way has a Catholic imprint, that there is some treatment of the Catholic Intellectual Tradition. This study reviewed the lead academic statement on colleges' websites. Not surprisingly, almost all schools showed this marker with $97.33 \%$ of them making it clear that the Catholic tradition would be part and parcel to the academic programs. Understandably, the Catholic character can be communicated in academic programs in several ways and most important is the student and faculty interaction in the teaching/learning process. A thorough examination of the curriculum is beyond the scope of this study, but it is encouraging that a high number of colleges explicate their Catholicity in their lead academic statement. However, there is certainly room for improvement when the balance of colleges has lead academic statements no different than secular colleges or other Christian churches. For example, Immaculate Concepcion College proclaimed "A lifegiving and innovating school community committed to transforming ICCnians into Christ-centered members of society". Holy Infant College described itself as "a community committed to excellence in education and to integral formation of all learners in an environment of Christian faith, compassionate love, justice and peace, and integrity of creation towards responsible stewardship in the Church and Philippine Society". All of these statements passed the criterion on the marker of lead academic statement. But compare these lead academic statements with La Consolacion College Manila which says "La Consolacion College Manila is a 
Catholic educational institution that is inspired by St. Augustine's vision of the academe that is founded on the primacy of love. It understands the academic community to be above all else, a scholarly fellowship of friends." Same is true with University of Perpetual Help on its statement which says "It shall inculcate Christian values - Catholic in doctrine as a way of strengthening the moral fiber of the Filipino." These lead academic statements suggest a vivid declaration of the schools' Catholic identity which is clearly emphasized in Ex Corde Ecclesiae. These are also expressions of the schools' fidelity to the teachings of the Catholic Church. Thus, it can be argued that, based on the findings Philippine colleges and universities followed the expectation in Ex Corde Ecclesiae for them to make known their Catholic identity through public documents such as vision, mission statement and goals.

This study shows that a large percentage (almost 95\%) of Catholic colleges in the Philippines explain to viewers of their websites their historical roots with their sponsoring religious organizations. A viewer can learn a lot about the colleges' religious tradition, history, values, and character. For most of the colleges, information is readily available from the home page, and the religious tradition and affiliation and its meaning for the students' experience permeate throughout the webpages. We recognize that the nature and extent of the sponsoring entities of colleges varies along the lines of governance, financial resources, teaching, and their overall involvement in mission and ministry and this cannot always be judged simply by viewing the college's website. However, it is evident from this study that schools that ostensibly are Catholic in the Philippines make their religious sponsors' influence known.

Similar to sponsorship above, colleges in this study make their Catholic Heritage known via Catholic symbols, artwork, and photographs. Over 73.33\% of the Catholic colleges in the Philippines that have a website make liberal use of Catholic images that would lead one to believe that it is a Catholic, and not a secular, college. Images that are quite common include crucifix, images of saints, image of the congregation's founder, liturgical symbols, chapel, image of Christ and other Christian icons and symbols. The Catholic Church is known for its abundance in terms of symbols, icons, artworks and other sacramentals. Similarly, a website of a Catholic school can make use of Catholic Heritage to uphold its identity as Catholic.

With such strong Catholic religious order presence in the life of a college, it would be expected that "service" would frequently be and intensely communicated. We learned that $60 \%$ of the colleges with a website made service 
by students and the college community known to its viewers. Service needs to be an integral part of the life of a college and formation of an educated person because it is an act of love which makes him/her a worthy son/daughter of God. Hence, Catholic schools make known the community engagement/extension office activities which provide opportunities to all members of the community to extend service to the least of the society. As reflected in the different programs under these offices, the main purpose of emphasizing service to others is to help the poor in society. However, it is also beneficial to the school members because it provides formation in the rationale and practice of service and justice for others.

The colleges did not do so well in explicating Catholic identity in the remaining three markers: "Catholic" on homepage, worship, and Catholic identity on the human resources pages. Using the term "Catholic" on the home page is a clear and expeditious way of communicating Catholic identify, if simply nominally. In fact, one would expect that if a college is ostensibly Catholic, then the Catholic identity would be clearly evident on the college's home page. In this study, we learned surprisingly almost $80 \%$ of the schools did not use the qualifier "Catholic" on their home pages to alert the reader to this type of higher education. The absence of the term Catholic on such a high number of college websites bears questioning. Is this because these schools believe they are known as Catholics being in a country whose population largely belongs to the Catholic Church? Is it a sign of leniency in promoting their Catholic identity? These questions need to be asked if only to alert those responsible for websites to maximize this medium to explicate the school's Catholic identity. On the other hand, it can be argued that Catholic affiliation based on the school's relationship to a religious order is enough pronouncement of the school's Catholicity. If the school management sees the website as an important means of asserting the school's identity, a great deal of planning and designing is expected. It is understood that participation of top level management in this regard would surely change the whole concept of the school's homepage.

Only $50 \%$ of the Catholic colleges that had a website included easily accessible information about campus ministry activities such as Holy Eucharist, confessions, devotions, spiritual development, feast days, and service. Types of worship and spiritual development should be prominent in the life of a Catholic College. As explained in the Ex Corde Ecclesiae, schools should provide avenues for practical demonstration of faith and these include the sacraments with particular emphasis on the Holy Eucharist.

Some of the schools showed pictures in the gallery of religious or liturgical services, but there is no section solely for the Campus Ministry Office. Moreover, 
little can be seen as to the programs and activities where the members of the school community can participate. This is quite surprising knowing that it is part of the tradition of the Catholic Church to include different religious and liturgical worship and services. The most common features that can be seen in the website are the academic offerings, promotions and news of achievements. But for those schools which have a separate and easily accessible Campus Ministry section, everything is almost explained as to the purpose of the office, the different planned activities and the regular celebration of liturgical and religious worship and services. It is worth noting that this section should have been given emphasis because, compared to a secular college or university, the Campus Ministry makes Catholic schools unique and different. Again, it is possible that students on these campuses are quite knowledgeable about campus ministry activities, but one would expect this to be highly visible in a medium that places such a broad and prominent role today.

The final marker discussed, and one that leaves us at a loss is the total absence of Catholic identity given on human resources or hiring practices of the college. Few colleges had this type of information on their website, and when a section was devoted to or alluded to the human resources activities there was nary a word about Catholic identity. It is fair to say that the most controversial aspect of $E x$ corde Ecclesiae in some countries, for example in the U.S., has to be the encyclical's expectation that a critical mass of faculty and senior administrators should be Catholic and that the theologians at Catholic colleges are teaching authentic Catholic doctrine (Monan \& Malloy, 1999). This does not suggest that Catholic colleges do not hire non-Catholics or that non-Catholics be discriminated. However, it is a reasonable expectation to convey to all current and prospective employees at Catholic colleges the college's Catholic heritage, mission, and purpose and that this needs to be respected by all employees. Clarity of what the schools expect from their employees is a strong testament of asserting Catholic identity. It sends a message that even if one is not a Catholic he/she must bear in mind that the school is founded on Catholic principles, virtues and beliefs.

Assuming that our seven attributes have some level of sensitivity of meaning in communicating Catholicity on a school campus, there is an improvement to be made. None of the 75 schools examined had the presence of all seven Catholic identity attributes. It is reasonable to expect that Catholic colleges would be using more rather than fewer of these attributes, and, if not, there should be a good explanation for why not. There could be a need for a deeper understanding of the Ex Corde Ecclesiae. Again, the purpose of the study was focused on how the schools explicate their Catholic identity via the official website. The absence 
of one or more markers does not diminish a school's Catholicity. There are other areas which are not reflected in the website that clearly reveal Catholic identity. However, the result of this study should be given much attention knowing the power of the internet and the effectiveness and accessibility of the school's website about the school's identity.

It is the authors' desire to provide a consumer's glimpse for looking at the Catholicity of Catholic colleges and universities in the Philippine, through their official websites. However, it is understood that this study did not confirm nor deny the strength of the schools' Catholicity. For example, do schools with six markers present in the websites better than those with only one or two? The study only investigated the presence of these markers but did not judge the totality of a particular level of Catholicity.

While the researchers studied on the academic statement, they did not dwell into full content analysis. The method was only to find the Catholic marker in these statements. Thus, interpretation of how Catholic the schools are under study is within the context of the method being employed. Similar to the study of Gambescia \& Paolucci in the U.S. (2012), this research project was conducted to get an aggregate significance of how the schools under study communicate their identity via official websites.

\section{CONCLUSIONS}

The findings of this study are significant and may be surprising to many school administrators and policy making bodies. They may want to review seriously and consider the nature and extent of Catholic identity currently on their websites to maximize the power of this medium in explicating the school's Catholic identity. With almost all schools having a Catholic identity embedded in their lead academic statement, it can be argued that the schools under study showed seriousness and determination of elucidating their Catholic identity. If the vision, mission, and goals are strategically displayed in the offices and other places in the school campus, this same strategy could be applied on the website if only to gain the same desired result.

In the absence of a Catholic marker in the lead academic statement, website visitors will have an impression that the school, even if ostensibly Catholic, may be no different from a secular school in its academic formation. Similar to the strong and consistent presence of Catholic identity in the lead academic statement, there is evidence of strong Catholic identity by the schools explanation of its Catholic affiliation. This shows how schools take pride in their attachment either to an 
order or a diocese. Having this marker obviously communicated in the website suggests a rich foundation which reveals a true mark of Catholic identity. With roughly $70 \%$ having Catholic Heritage on their website, much has to be done since this is considered to be the most obvious marker of Catholic identity. In fact, this marker poses as an initial introduction of the school's identity. It is the most visible marker, after all, and which does not need much explanation.

Results of this study also suggested that schools should pay much more attention to Catholic service, Catholic worship, "Catholic" nominally on the homepage and Catholic identity on the human resource page. One of the aims of having a website is to provide access for stakeholders particularly future clients about the school. If they intend to enroll in a Catholic school and upon visiting the website they could not find clear and frequent signs of its Catholicity, they might be discouraged and instead find other Catholic schools. Only 21.33\% of the school has Catholic marker in the homepage. If schools are serious in promoting its Catholic identity, it is very easy to make little changes in the homepage. This only requires a web designer or anybody in-charge of the website to make sure this Catholic marker is easily viewed. However, technical details are easy to accomplish. What is needed is a careful planning on how to make the school's identity stand out in the official website, not just in the homepage. Naturally, if the framework and plan are in place, putting the word Catholic in the homepage is a non-negotiable issue.

A great deal of concern surrounds how schools communicate high Catholic identity via its human resource department activities and services. This marker was non-existent in our review, meaning this is not a concern at all for the schools under study. If the result of this study is of great importance for school administrators, something must be done in this area. On other hand, with only half of the schools showing Catholic worship in their website, there must be a deep reflection and assessment to be done. Catholic expressions of faith are more visible with the different liturgical services in the school. The assumption could be that these services are conducted but are not reflected in the website. However, if the idea of explicating Catholicity includes this very important marker, then it must be well communicated.

This study used seven markers. There are other aspects in the school which can maximize the potential of realizing its vision and mission through its official website. There are other research questions which are worth investigating as a result of the findings of this study. For instance, how the schools manage the website with careful consideration of their identity as Catholic institutions? Are the guidelines stipulated in Ex Corde Ecclessiae considered and used in crafting 
the school's academic statements? Are those responsible for managing the schools websites aware of their duty vis a vis the Catholic principles and values? How serious are the schools in explicating Catholic identity through public documents, including school websites? What are other Catholic markers to be used for review?

The school's website serves as a powerful tool for stakeholders, particularly parents and students, in learning about the history, mission, purpose, activities, and student experience at the school. For those who are planning to enroll in a school, a website rich with Catholic markers gives the right impression and needed information.

\section{LITERATURE CITED}

Aklan Catholic College (2013). Home page. Retrieved on October 1, 2013 from http://goo.gl/DXh7o6

Ateneo de Davao University Website (2013). Home page. Retrieved June 10, 2013 from http://www.addu.edu.ph/.

Ateneo de Manila (2013). Home page. Retrieved June 10, 2013 from http://www. admu.edu.ph/.

Binangonan College (2013). Home page. Retrieved October 1, 2013 from http:// www.bcc.edu.ph/.

Brennan, M. (2012). Fostering Community through the House System at Most Holy Trinity Catholic School. Catholic Education: A Journal of Inquiry and Practice, Vol. 15, No. 2, 325-356. Retrieved on October 1, 2013 from http:// goo.gl/DA0VZ2

Cainta Catholic College (2013). Home page. Retrieved on October 1, 2013 from http://goo.gl/eAncXt

Canossa College (2013). Home page. Retrieved on June 3, 2013 from http://goo. $\mathrm{gl} / \mathrm{qW}$ t3Qc

Colegio de Purisima (2013). Home page. Retrieved on June 10, 2013 from http:// goo.gl/R8TFnu 
Colegio San Agustin-Bacolod (2013). Home page. Retrieved on June 3, 2013 from http://goo.gl/0TUIDQ

Columban College (2013). Home page. Retrieved on June 3, 2013 from http:// goo.gl/oH9bsG

Congregation for Catholic Education (1977). The Catholic School. Retrieved on October 1, 2013 from http://goo.gl/ZkqXSd

Convey, J. J. (2012). Perceptions of Catholic Identity: Views of Catholic School Administrators and Teachers. Catholic Education: A Journal of Inquiry and Practice, 16(1), 187-214. Retrieved on June 3, 2013 from http://goo.gl/ eOxuvp

Cor Jesu College (2013). Home page. Retrieved on June 3, 2013 from http://goo. $\mathrm{gl} / \mathrm{uCcFKV}$

De Guzman, L. (2011). Philippines still top Christian country in Asia, $5^{\text {th }}$ in world. Philippine Daily Inquirer. Retrieved on February 7, 2013 from http:// goo.gl/uGtd9Z

Gambescia, S.F. \& Paolucci, R. (2011). Nature and extent of Catholic identity communicated through official websites of U.S. Catholic colleges and universities. Catholic Education: A Journal of Inquiry and Practice, 15(1), 3-27. Retrieved on February 7, 2013 from http://goo.gl/a4f7Yo

Glazer, N. (2014). Catholic School Closures and the Decline of Urban Neighborhoods: What Is the Cause, and What the Effect?. Education Next, 14 (4), 81. Retrieved on May 7, 2014 from https://goo.gl/jwf8U4

Holy Infant College (2013). Home page. Retrieved on June 3, 2013 from http:// goo.gl/Aht $2 \mathrm{kR}$

Holy Name University (2013). Home page. Retrieved on June 3, 2013 from http://goo.gl/gsHilo 
Immaculate Concepcion College (2013). Home page. Retrieved on June 10, 2013 from http://goo.gl/ypJgxF

John Paul II (2005). Rapid Development. Retrieved on February 3, 2013 from http://goo.gl/Ewqmjd

John Paul II (1990). Ex Corde Ecclesiae. Retrieved on February 10, 2013 from http://goo.gl/jxvv0H

Klein, A. (2005). Look to the web to increase recruitment. University Business, 8(I), 37-39. Retrieved on February 3, 2013 from http://goo.gl/UGLFla

Krebbs, M. (2012). Content and Culture: Fostering Catholic Identity through an Integrated Curriculum. Catholic Education: A Journal of Inquiry and Practice, 16(1), 183-186. Retrieved on February 10, 2013 from http://goo.gl/vvcTIv

La Consolacion College (2013). Home page. Retrieved on June 3, 2013 from http://goo.gl/dC04LN/.

Miriam College (2013). Home page. Retrieved on June 10, 2013 from http://goo. $\mathrm{gl} / \mathrm{dCzaH} 2$.

Monan, J. D., \& Malloy, E. (1999). 'Ex corde Ecclesiae' creates an impasse. America, 180(3), 6-12. Retrieved on June 3, 2013 from http://goo.gl/9xKUrU

Musil, S. (2013 ). Pope blesses Twitter, Facebook to spread Church teachings. CNET News. Retrieved on August 19, 2013 from http://goo.gl/zXDfev.

Notre Dame of Dadiangas University (2013). Home page. Retrieved on June 10, 2013 from http://goo.gl/1gD6wR.

O'Connel, D. (2012). Catholic School, our Hope. Catholic Education: A Journal of Inquiry and Practice, 16(1), 155-162. Retrieved on August 19, 2013 from http://goo.gl/zWKQxK

Petrusch, S. M. (2011). CHOOSING A CATHOLIC COLLEGECONNECTING THE MIND AND HEART. Momentum, 42, 82-82, 84. 
Retrieved from https://goo.gl/qpL99f

San Sebastian College (2013). Home page. Retrieved on June 10, 2013 from http://goo.gl/WgfReL

Solan, A., \& Gambescia S. F. (2010). Attributes used to promote adult continuing education degree programs in a metropolitan newspaper. Journal of Continuing Higher Education, 58(2), 73-84. Retrieved on August 19, 2013 from http://goo.gl/CK71aB

St. Louis University (2013). Home page. Retrieved on June 10, 2013 from http:// goo.gl/xh5fop.

St. Paul University Manila (2013). Home page. Retrieved on October 1, 2013 from http://goo.gl/Wi0rbI.

St. Paul University Surigao (2013). Home page. Retrieved on June 3, 2013 from http://goo.gl/Ei8Ezy.

St. Scholastica College (2013). Home page. Retrieved on October 1, 2013 from http://goo.gl/4OTrgy.

Stoner, M. (2004). How the web can speak to prospective students. Chronicle of Higher Education, B10-11. Retrieved on June 3, 2013 from http://goo.gl/ n4LNRk

Urius University (2013). Home page. Retrieved on June 3, 2013 from http://goo. $\mathrm{gl} / 24 \mathrm{Ptz} 7$

University of Perpetual Help (2013). Home page. Retrieved on June 10, 2013 from http://goo.gl/Ukpdtp.

Xavier University (2013). Home page. Retrieved on June 10, 2013 from http:// goo.gl/Dgmepx. 